\title{
The Effect Of Earnings Per Share Categories On Share Price Behaviour: Some South African Evidence
}

\author{
Natasha Robbetze, North-West University, South Africa \\ Rikus de Villiers, North-West University, South Africa \\ Lana Harmse, North-West University, South Africa
}

\begin{abstract}
Earnings per share (EPS) is considered as an important accounting indicator of risk, entity performance and corporate success. It is used to forecast potential growth in future share prices, because changes in EPS are often reflected in share price behaviour. Companies listed on the Johannesburg Share Exchange (JSE) are required to publish three different categories of EPS: basic, diluted and headline EPS. It has become apparent that there is no indication as to which category explains share price behaviour best. The study therefore aimed to determine which category of EPS is best associated with share prices of the top 40 JSE listed companies in South Africa. No South African studies have previously attempted to answer this question. The top 40 JSE listed companies were selected as the research sample and the relationship between different categories of EPS and share prices was analysed empirically for the period 2005 to 2013. This study demonstrated that basic EPS correlated best with the changing behaviour of share prices. Furthermore, the study established that headline EPS proved to deliver lower correlation coefficients than other EPS categories. Based on the findings of this study some useful recommendations and areas for further research were also identified.
\end{abstract}

Keywords: Earnings; Earnings Per Share; Investors; Share Price Behaviour

\section{INTRODUCTION}

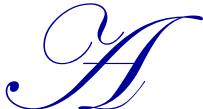

set of financial statements has several purposes, such as providing comparable, verifiable, timely and understandable economic information (Oberholster, Koppeschaar, Janse van Rensburg, Binnekade, Hattingh, De Klerk, Rossouw \& Du Toit, 2011). Among these, the primary purpose is to inform investors and potential investors about the activities, profitability and financial position of an entity for a specific period (Adams \& Media, 2014). Furthermore, investors also collect copies of annual financial statements and compare the results and numbers to those of other companies in order to predict which entity would render the best return on their investment (Adams \& Media, 2014; Moles, Parrino \& Kidwell, 2011).

According to conventional financial theories, investors base investment decisions on the rationale of risk and return considerations (Brigham \& Ehrhardt, 2007; Jagongo \& Mutswenje, 2014). There is therefore a direct relationship between risk and return - when risk is higher, the investor will expect a higher return to compensate for the absorption of high risk and possible loss (Moles et al., 2011; Reynders, Lambrechts \& Scheurkogel, 1984) with the opposite being true of lower risk investments.

Blume and Friend (1978) were of the opinion that volatile earnings are a primary indication of risk to the investor. Minton, Schrand and Walther (2002) support this view by arguing that investors prefer to invest in entities that have less volatile earnings, because the forecasting of such earnings is simpler and the investment appears less risky. Furthermore, investors are also concerned with future yields and use historical financial information to predict future returns (Baker \& Haslam, 1973), because historical results and past trends provide clues regarding future potential (Hinman, 2014). Investors therefore analyse financial information and invest in entities that are able to provide growth. 
A significant benchmark in quantifying such growth is to measure the earnings per share (EPS) trends of the entity (May, 1968). Smart and Graham (2012) concur by suggesting that an entity's growth rate is determined by performance indicators such as EPS which is disclosed in the financial statements of companies according to the specifications of the specific accounting standards applied in the respective country. Furthermore, authors have argued that EPS has become a useful investment decision tool for investors, because it indicates future prospects and growth (Mlonzi, Kruger \& Ntoesane, 2011).

According to the International Accounting Standard (IAS) 33: Earnings per share, an entity that trades equity instruments on public markets is required to disclose EPS as part of its financial statements (BDO, 2014; IFRS, 2014). EPS is a calculation that allocates a company's profits to each of its ordinary shares (Vaidya, 2014). It serves as an indication of profitability by measuring the entity's performance in relation to share capital that is employed to generate such returns (Koppeschaar, Sturdy, Du Toit, Deysel, Rossouw, Van Wyk, Gaie-Booysen, Papageorgiou \& Van der Merwe, 2013). For the purpose of measuring EPS, provision has been made for three categories of EPS, namely basic EPS, diluted EPS and headline EPS (BDO, 2014).

Basic EPS is the simplest form of EPS (Vaidya, 2014). For the purpose of calculating basic EPS, profit or loss attributable to the holding entity must be adjusted for after-tax amounts of preference dividends (IFRS, 2014). Basic EPS divides the actual earnings after preference shares by the weighted average number of ordinary shares (Dunn, 2010). Diluted EPS is more complex than basic EPS (Kennon, 2014). Diluted EPS expresses the EPS that an entity would generate if all warrants, convertibles and options have been exercised, causing the total ordinary share capacity to increase (Koppeschaar et al., 2013). In calculating diluted EPS, the total basic earnings are adjusted for any aftertax savings that would arise when convertible instruments are exchanged for ordinary shares before it is divided by the increased number of ordinary shares (BDO, 2014). Increases in the quantity of ordinary shares typically result in a lower and, thus, diluted EPS (Kennon, 2014). Furthermore, both basic and diluted EPS of an entity must be disclosed on the face of the Statement of Profit or Loss and Other Comprehensive Income (BDO, 2014).

In South Africa specifically, all companies listed on the JSE are required to publish headline EPS as a listing requirement (SAICA, 2013). Headline EPS is calculated by excluding separately identifiable re-measurements from the earnings of the entity (Steenkamp, 2013). The headline earnings can be calculated by using the basic earnings and adding back or deducting any items that are excluded from headline EPS (Steenkamp, 2013). Headline earnings are divided by the weighted average number of shares in order to calculate headline EPS (Bragg, 2013). Diluted headline EPS is also calculated by dividing headline earnings, adjusted for any after-tax savings that would arise when convertible instruments are exchanged for ordinary shares, by the weighted number of ordinary shares, adjusted for any potential ordinary shares that might be issued (Bragg, 2013). Headline EPS is often used by investors for comparative purposes and provides a single earnings number that describes the performance of the entity (SAICA, 2013).

From the age old arguments of May (1968) and the more recent of Smart and Graham (2012) noted earlier, it is evident that growth rates in historical earnings can be used to establish possible future increases in growth potential. It is argued that EPS plays a significant role in the investment decisions taken by investors, because EPS trends can be used to measure risk and performance. In addition, it is important to study the relationship between EPS and the share price of shares. Brigham and Ehrhardt (2007) posited that EPS signals prospects to investors. EPS is therefore an indication of shareholder's wealth and, should EPS increase, increases in the value of the share will be expected (Mkhonza, 2007). Balsam and Lipka (1998) contended that earnings explain share price behaviour, because the relationship between accounting EPS and share prices have been extensively studied. Chang, Su, Chen and Chang (2008) also concur by explaining that EPS influences share prices in the long run.

The effect of EPS on share price behaviour have been extensively researched internationally over the last three decades. Abroad, most of the focus was on determining the relationship between EPS and share price behaviour (e.g. Almumani, 2014; Chang et al., 2008; Demsetz, 1995; Haque \& Faruquee, 2013; Lev, 1989; Menaje, 2012; Menike \& Prabath, 2014; Sharma, 2011). Locally in South Africa, limited studies by Auret and De Villiers (2000), De Villiers, Hamman, Joubert and Le Roux (2003), De Wet and Du Toit (2007) and Erasmus (2010) also investigated the relationship between EPS and share prices. One distinct discourse was noted from these studies, which is that EPS had a significant correlation with share price behaviour. 
Evidently, researchers have proven that an association exists between earnings information and share price behaviour, while few research studies have attempted to identify a category of EPS that can associate best with changing share price behaviour. Furthermore, limited studies have been conducted to determine which category of EPS best explains the behaviour of share prices. The latter is also specifically true within the South African context. This study is therefore aimed at filling this gap in South African literature specifically by determining which category of EPS is best associated with share prices of the top 40 JSE listed companies in South Africa.

The findings of this study also does not only contribute to reduce the shortage of literature on this phenomenon in South Africa, but also internationally, as very few research has been done to determine which category of EPS best associates itself with share price behaviour globally. The findings of this study should also be useful to investors and other stakeholders globally, as IAS 33, which is used to calculate EPS, is an internationally applied accounting standard. Furthermore, researchers argued that investors, regulators and accounting practitioners valued earnings data and that earnings information contained great informative content which could be related to share price behaviour which stresses the value of empirically analysing accounting earnings EPS (Lev, 1989; Chang et al., 2008). The findings will therefore be of value and bring investors and other stakeholders some more clarity on what category of EPS they should rely on when making investment decisions.

Against the backdrop, the remainder of the article provides a synopsis on some previous research performed on EPS and share price behaviour. This is subsequently followed by a discussion on the research design and a detailed discussion of the study's findings. Finally, a conclusion is drawn, recommendations are made, limitations are recognised and areas for further research are suggested.

\section{PREVIOUS RESEARCH}

As noted in the introduction of this study, the relationship between EPS and share price behaviour have been given much attention over the last three decades globally. Abroad, Lev (1989) questioned the usefulness of accounting EPS. The main objective of this study was to determine whether or not accounting EPS should be relied on by investors (Lev, 1989). Lev (1989) found that the correlation between earnings and share prices were low. It was suggested that earnings make a modest contribution to movements that are observed in share prices (Lev, 1989). Demsetz (1995) attempted to find a method that can be applied in order to measure the relationship between share prices and EPS for the period 1962 to 1981. Demsetz (1995) constructed multiple linear regressions for each year, where each regression contained 20 variables - one contemporaneous EPS variable and 19 other lag and lead EPS variables. It was concluded that contemporaneous EPS variables had a greater impact on share prices than lag or lead EPS variables.

Furthermore, Nichols and Wahlen (2004) aimed to analyse the relationship between earnings information and share returns from the New York Share Exchange, AMEX and NASDAQ for the period 1988 to 2002. The results indicated that share returns were significantly related to earnings and that share prices responded strongly to earnings information (Nichols \& Wahlen, 2004). It was also found that greater returns were associated with higher earnings persistence and vice versa and that share prices reacted rapidly to new earnings information, but when extreme earnings surprises occurred, market reactions were incomplete. Chang et al. (2008) investigated the relationship between share prices and EPS of electronic firms listed on the Taiwan Share Exchange. The study aimed to determine the degree to which the share prices responded to the EPS figure and whether a firm's growth rate could impact the relationship between share prices and EPS (Chang et al., 2008). A null hypothesis was used to analyse information, and the results indicated that share prices moved with EPS in the long run, but not necessarily at the same rate (Chang et al., 2008). Furthermore, an inverse relationship was found between growth rates in operating revenue and the EPS impact on share prices. When growth rates in operating revenue were higher, EPS trends correlated better with share prices (Chang et al., 2008).

The study by Sharma (2011) attempted to determine the relationship between share prices and the seven variables which included EPS, in order to establish financial factors that are useful to investors in India (Sharma, 2011). Variables were analysed for the period 1993 to 2009 and a linear multiple regression model was constructed with results indicating that EPS and dividend per share were able to correlate best with share prices (Sharma, 2011). The researcher concluded that both dividends and earnings contained explanatory power with regard to share price changes. Moreover, Menaje (2012) argued that share prices can often have a volatile nature. The main objective of 
the study was to identify financial measures that have a significant impact on share prices in the Philippines (Menaje, 2012). Two variables were selected for the study: EPS; and return on assets. The researcher performed an analysis on the 2009 financial reports. Information was collected from the OSIRIS data base. A Spearman Rank Order Correlation and a multiple regression model were applied and the results indicated that $73 \%$ of changes in share prices could be explained by means of EPS (Menaje, 2012). The researcher concluded that EPS had a significant impact on share prices, while ROA correlated negatively with share prices. Therefore, the application of EPS in the prediction of share prices was justified.

Haque and Faruquee (2013) conducted a study where the objective was to identify fundamental performance indicators and to determine which indicator could best determine share prices on the Dhaka Share Exchange (Haque \& Faruquee, 2013). The study indicated that EPS did not correlate with share prices. Almumani (2014) identified six variables that could influence share prices with one being EPS The objective of the study was to identify the quantitative factor that influences share prices of Jordanian Banks listed on the Amman Share Exchange (Almumani, 2014). The researcher obtained an empirical relationship by constructing a linear multi-regression model. From the results, it became evident that EPS had the highest correlation coefficient and, therefore, influenced share prices most (Almumani, 2014).

Menike and Prabath, (2014) attempted to provide guidance on a company's performance to the users of financial information (Menike \& Prabath, 2014). Three indicators of company performance was identified: EPS; dividend per share; and book value per share. A multi-regression model was compiled and the findings indicated that dividend per share was most useful in predicting share prices, followed by EPS and book value per share (Menike \& Prabath, 2014). In this study, $37 \%$ of movements in share prices remained unexplained. More recently, Iqbal, Ahmed, Zaidi and Raza (2015) aimed to identify variables that determine share prices of companies in the oil and gas, and cement industry, listed on the Karachi Share Exchange (Iqbal et al., 2015) for the period 2008 to 2013. A multiple regression model was constructed and the results suggested that EPS was a significant determinant of share prices in the industries that were researched (Iqbal et al., 2015). The researchers concluded that shares should be evaluated at the hand of EPS in both the oil and gas, and cement industries of the Karachi Share Exchange (Iqbal et al., 2015).

Locally, in South Africa, Auret and De Villiers (2000) identified both EPS and dividends per share as factors that influence share prices. The main objective of the study was to determine which factor had more explanatory power with regard to share prices (Auret \& De Villiers, 2000). The applicable data were obtained from the I-Net data base. A total of 67 industrial companies were selected from the JSE, and financial information between 1981 and 1997 was analysed. Multi-regression analysis was applied. The results suggested that EPS was a better explanatory variable than dividends per share (Auret \& De Villiers, 2000). It seemed, therefore, appropriate for investors to rely on earnings analysis when share prices were being predicted. It was concluded that EPS was a meaningful accounting measurement. It was argued that both factors could potentially signal firm value and affect share prices.

More work on South African soil included studies by De Villiers et al. (2003) and De Wet and Du Toit (2007). De Villiers et al. (2003) suggested that EPS and cash flow per share can explain share price behaviour. The empirical results indicated that changes in EPS could better explain changes in share prices than cash flow per share (De Villiers et al., 2003). De Wet and Du Toit (2007) on the other hand identified six performance indicators of a firm which included EPS. The linear regression between the six performance indicators and shareholder's returns were measured and the results indicated that none of the performance measures displayed a strong relationship to shareholders return (De Wet \& Du Toit, 2007).

Finally, Erasmus (2010) attempted to determine whether the value of a company's share price can be influenced by many factors. Among these factors are EPS, dividends per share and cash flow per share (Erasmus, 2010). The study aimed to determine the relationship between share prices and volatilities in EPS, dividends per share and cash flow per share, in order to determine which of the three factors correlated best with share price behaviour. The researcher performed both a Spearman Rank Order correlation analysis and a multiple regression analysis. The results indicated a significant relationship between share prices and volatility of EPS and dividends per share, where EPS delivered the highest correlation coefficients (Erasmus, 2010). Cash flow per share volatility did not have a significant relationship with share prices. It was concluded that both EPS and dividends per share were important considerations to the investor (Erasmus, 2010). 
As can be derived from the previous studies, researchers have formed different opinions on the relationship between EPS and share prices with one overarching conclusion noted that EPS can significantly affect share price behaviour. Finally, it should be noted that care should, however, be applied when drawing parallels between the outcome of this study and possible international research outcomes, since USA-based entities apply the Statement of Financial Accounting Standard (SFAS) 128 and not IAS 33 which is required from South African entities.

\section{RESEARCH DESIGN}

The research design of this study was designed to reach the research objective which aimed at determining which category of EPS is best associated with share prices of the top 40 JSE listed companies in South Africa. This study therefore applied convenience sampling as the top 40 JSE listed companies in South Africa were selected to be included in this study. The sample size was selected due to convenience and accessibility, as well as the fact that these companies have the 40 highest market capitalisation rates in South Africa. Consequently, the sample size was also equal to the population of the study, which can contribute to worthy research findings.

The study required two data sets to be collected: EPS figures and share prices. Financial information was analysed for a period of nine years - 2005 to 2013. This period was selected as IAS 33 only became effective on 1 January 2005 and the final financial results were only available for financial years ending 2013 at the time the study was conducted. Three different share prices were selected in measuring statistical relationships: the share price 20 days before the publication of EPS (20BP), on the day of publishing (PD), and 20 days after publication (20AP). In selecting three share prices, the study takes into account that market participants could react to EPS information prematurely, immediately or later. The approach is supported by Morse et al. (2011), who argued that a short event window can measure the impact of a new event on investment behaviour. Data relating to EPS information was collected from the INET BFA data base (2015), while information that relates to share prices was collected from the Sens data base (2015) in line with previous South African studies (e.g. Auret \& De Villiers, 2000).

\section{DATA ANALYSIS}

When quantitative research is performed, the researcher attempts to make sense of a phenomenon by analysing numerical data (Leedy \& Ormrod, 2001). In this study, two statistical methods were applied:

- Correlation modelling by means of calculating the Pearson product moment coefficients and R square;

- $\quad$ Paired t-testing

According to Field (2009), correlation coefficients describe the relationship between variables by indicating whether they are positively related, negatively related or unrelated to one another. For the purpose of this study, correlation was measured by means of applying two methods: the Pearson product moment coefficient and an R square. The Pearson product moment coefficient (r) assists in the measurement of relationships (Field, 2009). Correlation coefficients evaluate relations by providing a score between -1 and 1 , where -1 represents the perfect negative relationship and 1 the perfect positive relationship (Field, 2009). The Pearson product moment coefficient can be used to calculate an $\mathrm{R}$ square. $\mathrm{R}$ square is indicative of the shared variance between variables (Pallant, 2013). It suggests how much of the variance in a variable can be explained by another variable (Pallant, 2013). For the purpose of this study, Pearson product moment correlation coefficients and R squares were calculated among EPS categories and selected share prices to determine if the various EPS categories effect share price behaviour.

Paired t-testing compares the mean scores obtained when different tests are performed on one group of participants (Huizingh, 2007). Paired t-tests indicate whether there are statistically significant differences between mean scores of data sets (Pallant, 2013). Should a result be obtained where $\mathrm{p}<.05$, it can be accepted that a significant difference in mean scores exist and that differences did not occur by chance (Pallant, 2013). T-tests were performed in this study as to determine which category of EPS, based on the results of the Pearson product moment correlation coefficients and $\mathrm{R}$ squares, have a greater effect on share price behaviour.

When correlation modelling and t-testing are performed, an important statistical assumption should be made, namely that the variables are normally distributed (Pallant, 2013). After collecting the data in this study, it was discovered that 
the variables were not normally distributed. For this reason, the data had to be transformed. The transformation of data enables a researcher to obtain distributions that look more normal (Pallant, 2013). Transformation does not influence the relationship among variables, but all variables should be converted in the same manner (Field, 2009). For the purpose of this study, variables were transformed into natural logarithmic format. Overall, the selection of the statistical methods are in line with similar studies performed by Erasmus (2010) and De Villiers et al. (2003). In applying the relevant statistical methods, the BMI SPSS Statistics Software (Version 22.0 for Windows) was used.

\section{RESULTS}

The statistical analysis of the study was organised in two steps: first the correlation analysis was performed, and thereafter paired t-tests were executed. The results of each step are discussed next.

\section{Correlation Results}

The correlation results for each category of EPS for the years 2005 to 2013 are summarised in Table 1 below.

Table 1. Correlation results for each category of EPS from 2005 to 2013

\begin{tabular}{|c|c|c|c|c|c|c|c|c|c|c|c|c|}
\hline & \multicolumn{4}{|c|}{ LogBasic EPS } & \multicolumn{4}{|c|}{ LogDiluted EPS } & \multicolumn{4}{|c|}{ LogHeadline EPS } \\
\hline \multicolumn{13}{|l|}{2005} \\
\hline $\mathrm{PD}$ & $.54^{* *}$ & 36 & .001 & .292 & $.52^{* *}$ & 36 & .003 & .267 & $.46^{* *}$ & 36 & .007 & .207 \\
\hline 20BP & $.54^{* *}$ & 36 & .001 & .291 & $.52^{* *}$ & 36 & .003 & .270 & $.46^{* *}$ & 36 & .006 & .211 \\
\hline 20AP & $.53^{* *}$ & 36 & .001 & .284 & $.51^{* *}$ & 36 & .004 & .257 & $.45^{*}$ & 36 & .008 & .198 \\
\hline \multicolumn{13}{|l|}{2006} \\
\hline $\mathrm{PD}$ & $.49^{* *}$ & 37 & .003 & .239 & $.42^{*}$ & 37 & .016 & .179 & $.35^{*}$ & 37 & .041 & .120 \\
\hline 20BP & $.60^{* *}$ & 37 & .000 & .360 & $.58^{* *}$ & 37 & .000 & .341 & $.48^{* *}$ & 37 & .003 & .231 \\
\hline 20AP & $.61 * *$ & 37 & .000 & .368 & $.57^{* *}$ & 37 & .001 & .329 & $.50^{* *}$ & 37 & .002 & .250 \\
\hline \multicolumn{13}{|l|}{2007} \\
\hline PD & $.60^{* *}$ & 38 & .000 & .365 & $.59^{* *}$ & 38 & .000 & .345 & $.53^{* *}$ & 38 & .001 & .278 \\
\hline 20BP & $.60^{* *}$ & 38 & .000 & .358 & $.58^{* *}$ & 38 & .000 & .336 & $.52^{* *}$ & 38 & .001 & .266 \\
\hline $20 \mathrm{AP}$ & $.66^{* *}$ & 38 & .000 & .434 & $.60^{* *}$ & 38 & .000 & .355 & $.58^{* *}$ & 38 & .000 & .332 \\
\hline \multicolumn{13}{|l|}{2008} \\
\hline $\mathrm{PD}$ & $.65^{* *}$ & 39 & .000 & .421 & $.67^{* *}$ & 39 & .000 & .451 & $.67^{* *}$ & 39 & .000 & .412 \\
\hline 20BP & $.58^{* *}$ & 39 & .000 & .333 & $.59^{* *}$ & 38 & .000 & .352 & $.59^{* *}$ & 39 & .000 & .333 \\
\hline $20 \mathrm{AP}$ & $.64^{* *}$ & 39 & .000 & .403 & $.66^{* *}$ & 38 & .000 & .437 & $.66^{* *}$ & 39 & .000 & .396 \\
\hline \multicolumn{13}{|l|}{2009} \\
\hline PD & $.51 * *$ & 40 & .001 & 261 & $.48^{* *}$ & 40 & .004 & .23 & $.42 *$ & 40 & .016 & .172 \\
\hline 20BP & $.51 * *$ & 40 & .001 & .257 & $.48^{* *}$ & 40 & 004 & .23 & $.41^{*}$ & 40 & .017 & .171 \\
\hline 20AP & $.51 * *$ & 40 & .001 & .259 & $.49 * *$ & 40 & .003 & .24 & $.42 *$ & 40 & .014 & .180 \\
\hline \multicolumn{13}{|l|}{2010} \\
\hline $\mathrm{PD}$ & $.62^{* *}$ & 40 & .000 & .387 & $.60^{* *}$ & 40 & .000 & .359 & $.53^{* *}$ & 40 & .001 & .284 \\
\hline 20BP & $.62^{* *}$ & 40 & .000 & .384 & $.60^{* *}$ & 40 & .000 & .355 & $.53^{* *}$ & 40 & .001 & .280 \\
\hline 20AP & $.63^{* *}$ & 40 & .000 & .390 & $.60^{* *}$ & 40 & .000 & .364 & $.54^{* *}$ & 40 & .001 & .291 \\
\hline \multicolumn{13}{|l|}{2011} \\
\hline PD & $.66^{* *}$ & 40 & .000 & .440 & $.59^{* *}$ & 40 & .000 & .342 & $.57^{* *}$ & 40 & .000 & .319 \\
\hline 20BP & $.62^{* *}$ & 40 & .000 & .380 & $.51^{* *}$ & 40 & .000 & .259 & $.49^{* *}$ & 40 & .000 & .241 \\
\hline 20AP & $.67^{* *}$ & 40 & .000 & .443 & $.58^{* *}$ & 40 & .000 & .340 & $.56^{* *}$ & 40 & .000 & .315 \\
\hline \multicolumn{13}{|l|}{2012} \\
\hline PD & $.62^{* *}$ & 40 & .000 & .379 & $.61^{* *}$ & 40 & .000 & .370 & $.60^{* *}$ & 40 & .000 & .354 \\
\hline 20BP & $.61^{* *}$ & 40 & .000 & .377 & $.61^{* *}$ & 40 & .000 & .371 & $.59^{* *}$ & 40 & .000 & .352 \\
\hline 20AP & $.62^{* *}$ & 40 & .000 & .379 & $.61^{* *}$ & 40 & .000 & .375 & $.59^{* *}$ & 40 & .000 & .350 \\
\hline \multicolumn{13}{|l|}{2013} \\
\hline PD & $.52^{* *}$ & 40 & .002 & .267 & $.52^{* *}$ & 40 & .002 & .267 & $.45^{* *}$ & 40 & .005 & .201 \\
\hline 20BP & $.53^{* *}$ & 40 & .001 & .285 & $.53^{* *}$ & 40 & .002 & .279 & $.50^{* *}$ & 40 & .003 & .246 \\
\hline 20AP & $.53^{* *}$ & 40 & .001 & .283 & $.53^{* *}$ & 40 & .002 & .281 & $.46^{* *}$ & 40 & .004 & .210 \\
\hline
\end{tabular}

**Correlation is significant at the .01 level (two tailed)

*Correlation is significant at the .05 level (two tailed) 
Table 1 indicates that basic EPS provided the highest correlations for years 2005 to 2007 and from 2009 to 2013 . For 2008 , the highest correlation was obtained for diluted EPS. This deviation from the findings in previous years must be placed in economic perspective. During 2008, great economic instability prevailed due to an international financial crisis. It would seem that investors placed greater value on diluted EPS measurements during this time. Possibly, investors acted 'overly careful' with regard to their investments, leading to the preference of the diluted EPS measurement, because diluted EPS provides an earnings figure after all dilutive potential in earnings value has manifested itself. Investors could, furthermore, have anticipated that a company would convert financial instruments into ordinary shares for the sake of saving on interest and preference dividends during a time of financial pressure. It is also clear that LogDiluted EPS could best correlate with the share price on date of publication. This could serve as an indication that investors had acted upon financial information speedily.

Overall, the maximum share variances ranged between $26.10 \%$ and $44 \%$ for basic EPS. When objectively considering this range, it seems to be a rather large effect, because many other factors have an influence on investment decisions. For a single factor (basic EPS) to influence share prices between $26.10 \%$ and $44 \%$ is a rather significant impact. Headline EPS delivered the poorest correlations for all nine years under consideration. Evidently, headline EPS could least associate itself with share prices. Furthermore, it can also be noted that LogBasic EPS delivered higher correlation coefficients and shared variances than LogDiluted EPS and LogHeadline EPS overall. It would, however, seem that the differences in correlations among the selected EPS categories were rather small and that all correlations proved to be statistically significant $(\mathrm{p}<0.05)$. Before the research findings could be concluded upon, it had to be determined whether the differences in correlation coefficients were significant to determine which category of EPS had the greatest effect on share price behaviour. Therefore, paired t-testing was performed on the correlation results as noted earlier.

\section{T-Testing Results}

Table 2. T-test performed on correlations of LogBasic, LogDiluted EPS and LogHeadline EPS

\begin{tabular}{|c|c|c|c|c|c|}
\hline \multirow{2}{*}{ Pair } & \multirow{2}{*}{ Category of EPS and share price date } & \multirow{2}{*}{ Mean } & \multirow{2}{*}{$\begin{array}{c}\text { Std. } \\
\text { Deviation }\end{array}$} & \multicolumn{2}{|c|}{ T-tests } \\
\hline & & & & t-value & p-value \\
\hline 1 & $\begin{array}{l}\text { LogBasic EPS and LogShare price on PD } \\
\text { LogDiluted EPS and LogShare price PD }\end{array}$ & $\begin{array}{l}.58 \\
.55\end{array}$ & $\begin{array}{l}.07 \\
.08\end{array}$ & 2.36 & .036 \\
\hline 2 & $\begin{array}{l}\text { LogBasic EPS and LogShare price 20BP } \\
\text { LogDiluted EPS and LogShare price 20BP }\end{array}$ & $\begin{array}{l}.58 \\
.56\end{array}$ & .04 & 2.03 & .037 \\
\hline 3 & $\begin{array}{l}\text { LogBasic EPS and LogShare price 20AP } \\
\text { LogDiluted EPS and LogShare price 20AP }\end{array}$ & $\begin{array}{l}.60 \\
.57\end{array}$ & $\begin{array}{l}.06 \\
.06\end{array}$ & 2.34 & .037 \\
\hline 4 & $\begin{array}{l}\text { LogBasic EPS and LogShare price on PD } \\
\text { LogHeadline EPS and LogShare price on PD }\end{array}$ & $\begin{array}{l}.58 \\
.50\end{array}$ & $\begin{array}{l}.07 \\
.09\end{array}$ & 5.58 & .001 \\
\hline 5 & $\begin{array}{l}\text { LogBasic EPS and LogShare price 20BP } \\
\text { LogHeadline EPS and LogShare price 20BP }\end{array}$ & $\begin{array}{l}.58 \\
.50\end{array}$ & $\begin{array}{l}.04 \\
.05\end{array}$ & 6.21 & .000 \\
\hline 6 & $\begin{array}{l}\text { LogBasic EPS and LogShare price 20AP } \\
\text { LogHeadline EPS and LogShare price 20AP }\end{array}$ & $\begin{array}{l}.60 \\
.52\end{array}$ & $\begin{array}{l}.06 \\
.07\end{array}$ & 6.34 & .000 \\
\hline 7 & $\begin{array}{l}\text { LogDiluted EPS and LogShare price on PD } \\
\text { LogHeadline EPS and LogShare price on PD }\end{array}$ & $\begin{array}{l}.55 \\
.50\end{array}$ & $\begin{array}{l}.08 \\
.09\end{array}$ & 6.56 & .000 \\
\hline 8 & $\begin{array}{l}\text { LogDiluted EPS and LogShare price 20BP } \\
\text { LogHeadline EPS and LogShare price 20BP }\end{array}$ & $\begin{array}{l}.56 \\
.50\end{array}$ & $\begin{array}{l}.05 \\
.05\end{array}$ & 5.98 & .000 \\
\hline 9 & $\begin{array}{l}\text { LogDiluted EPS and LogShare price 20AP } \\
\text { LogHeadline EPS and LogShare price 20AP }\end{array}$ & $\begin{array}{l}.57 \\
.52 \\
\end{array}$ & $\begin{array}{l}.06 \\
.07\end{array}$ & 6.08 & .000 \\
\hline
\end{tabular}

*Correlations differ significantly at $(\mathrm{p}<.05)$

From table 2 it is observed that the average correlations between LogBasic EPS and LogDiluted EPS differed significantly, where the mean score of LogBasic EPS was greater. Furthermore, the average correlations between LogBasic EPS and LogHeadline EPS differed significantly, where the mean score of LogBasic EPS was greater; and finally, the average correlations between LogDiluted EPS and LogHeadline EPS differed significantly where the mean score of LogDiluted EPS was greatest. It is therefore clear that LogBasic EPS delivered the highest correlations on average and that LogBasic EPS had the greatest effect on share price behaviour, followed by LogDiluted EPS and LogHeadline EPS. Based on this finding, the study further attempted to determine whether LogBasic EPS associates 
itself better with any of the selected share prices. Table 3 below illustrates that none of the selected share prices led to a significant difference in correlations. From table 3 it can be posited that none of the selected share prices led to a significant difference in the correlations obtained. It can therefore be concluded that LogBasic EPS did not associate itself better with one of the selected share prices, because $p>.05$ for all observations. Although the closest correlation was found between pair 3 , this correlation was still insignificant.

Table 3. T-test performed on correlations of LogBasic EPS and share prices

\begin{tabular}{|c|c|c|c|c|c|}
\hline \multirow{2}{*}{ Pair } & \multirow{2}{*}{ Category of EPS and share price date } & \multirow{2}{*}{ Mean } & \multirow{2}{*}{$\begin{array}{c}\text { Std. } \\
\text { Deviation }\end{array}$} & \multicolumn{2}{|c|}{ T-tests } \\
\hline & & & & t-value & p-value \\
\hline 1 & $\begin{array}{l}\text { LogBasic EPS and LogShare price on PD } \\
\text { LogBasic EPS and LogShare price 20BP }\end{array}$ & $\begin{array}{l}.58 \\
.58\end{array}$ & $\begin{array}{l}.07 \\
.04\end{array}$ & .03 & .974 \\
\hline 2 & $\begin{array}{l}\text { LogBasic EPS and LogShare price on PD } \\
\text { LogBasic EPS and LogShare price 20AP }\end{array}$ & $\begin{array}{l}.58 \\
.60\end{array}$ & $\begin{array}{l}.07 \\
.06\end{array}$ & -1.35 & .213 \\
\hline 3 & $\begin{array}{l}\text { LogBasic EPS and LogShare price 20BP } \\
\text { LogBasic EPS and LogShare price 20AP }\end{array}$ & $\begin{array}{l}.58 \\
.60\end{array}$ & $\begin{array}{l}.04 \\
.06\end{array}$ & -1.66 & .068 \\
\hline
\end{tabular}

\section{DISCUSSION}

Based on the results of the study, it is clear that that basic EPS was able to relate best to share price behaviour, but proved to have no preference to one of the selected share prices. Headline EPS provided the lowest correlations and mean scores. Therefore, headline EPS seems to have a poorer relationship to share prices than other EPS categories. When the empirical findings of the study are compared to previous studies performed, both locally in South Africa and abroad, various similarities and some differences are noted.

Internationally, the American study performed by Lev (1989) suggested that the relationship between earnings and share prices is low. The findings of this study are contrary to Lev's (1989), because all categories of EPS proved to be significantly associated with share prices, either at a $1 \%$ or $5 \%$ statistical confidence level. The study of Lev (1989) was, however, performed in 1989, and the findings might be considered as outdated. The study by Demsetz (1995) acknowledged a strong association between EPS and share prices. Demsetz (1995) attempted to express this association statistically through the application of t-statistics. Similar to Demsetz's (1995) study, this study applied ttesting in its empirical analysis. The findings of this study support the arguments of Demsetz (1995). Furthermore, Nichols and Wahlen (2004) concluded that share prices strongly respond to earnings information, because earnings convey important clues about future prospects to the investor. The conclusion of Nichols and Wahlen (2004) is in line with this study, because EPS categories were significantly associated with share prices in the empirical analysis performed.

Chang et al. (2008) indicated that share prices and EPS move in the same direction. This finding is in line with this study, because the correlations obtained were positive, indicating that variables moved in the same direction and are therefore strongly correlated. Moreover, Sharma (2011) also found significant correlations between EPS and share prices, as well as dividends per share and share prices. Such findings are not unexpected, because dividends depend upon earnings. This study supports the arguments of Sharma (2011), because both studies indicate that EPS and share prices are related. Finally, Menaje (2012) demonstrated that EPS impacts share prices significantly, which is in line with the findings of this, as well as other studies by Almumani (2014) and Iqbal et al. (2015).

Furthermore, the research done in South Africa by Auret and De Villiers (2000) supports the outcomes of this study, because both studies indicate that EPS and share prices are significantly related. Moreover, De Villiers et al. (2003) determined whether dividends per share was a better explanatory variable for share prices than EPS. The study demonstrated that EPS was a better explanatory variable. The findings, again, support the outcomes of this study, because EPS categories were significantly associated with share prices. Finally, Erasmus (2010) indicated that both dividends and EPS can associate with share prices. EPS was, however, able to provide the highest correlation coefficients. 


\section{CONCLUSION AND RECOMMENDATIONS}

The primary objective was to determine which category of EPS (basic EPS, diluted EPS or headline EPS) best associates with share prices of the top 40 JSE listed companies. After the application of selected empirical methods, it was found that basic EPS was the most useful EPS category to investors, followed by diluted EPS. Headline EPS proved to be less useful to investors. From the findings of this study, it can be submitted that basic EPS has the greatest effect on the share price behaviour of the top 40 JSE listed companies.

It is submitted that investors should, therefore ultimately, consider basic EPS when investing in the top 40 JSE listed companies. In general, basic EPS associated best with the share price behaviour of these entities. It is, however, recommended for investors to analyse the economic climate when making investments, because diluted EPS seems to be able to provide meaningful associations with share prices in periods of economic recession.

Furthermore, the top 40 JSE listed entities can also benefit from the findings of the study which can serve as an indication of which category of EPS should enjoy greater attention. Entities are advised to pay attention to trends observed in basic EPS, because its interdependence with share prices proved to be the highest. Again, the top 40 JSE listed entities should also consider the general economic environment, because investors may focus on diluted EPS figures in times of great economic difficulty.

Finally, it is recommended that investors consider not only headline EPS when making investment decisions, because another EPS category might provide better indications with regard to share price behaviour. This recommendation is in line with the measurement requirements of IAS 33. The Standard does not require for headline EPS to be published, while it would seem that headline EPS does not convey important signs about share price performance of the top 40 JSE listed companies. It is acknowledged that the top 40 JSE listed entities will continue to disclose headline EPS, seeing that it is a JSE listing requirement. It is, however, not recommended that the publication of headline EPS as a JSE listing requirement for the top 40 JSE listed entities be reconsidered, because the findings of the study seem to indicate that the publication of the headline EPS category might be of little use to the investor. Furthermore, the top 40 JSE listed entities are not motivated to monitor headline EPS measurements, because other categories of EPS convey more important clues about share price behaviour to the investor.

\section{LIMITATIONS AND AREAS FOR FURTHER RESEARCH}

As is the case with any empirical study, this study was not without its limitations. The study measured statistical relations among EPS categories and share prices of the top 40 JSE listed companies. The generalisability of the findings to other companies and countries is, therefore, limited. Also, the study faced the challenge of multicollinearity. This created the limitation that EPS categories could not be used to predict share prices. However, it did not influence the ability to determine associations among variables, Furthermore, this research accommodated nine years of financial information. Empirical findings could be altered if financial information were to be analysed for significantly longer periods. Finally, the study relied on the accurate measurement of EPS figures. Earnings information can, however, be manipulated (Elmaleh, 2006:1) and such manipulations can distort the empirical findings.

Based on these limitations, some useful areas for further research can be identified. A similar study can be performed to test whether the share prices of different JSE sectors can be influenced by different categories of EPS. The analysis performed in this study can also be performed within another time frame to determine whether findings are significantly altered when a different period is taken under review. Furthermore, a similar analysis can be performed on other share exchanges (such as the NASDAQ) to observe whether similar findings are obtained. An investigation on how the manipulation of earnings information can lead to increases in share prices based on inflated EPS figures could also add value. 


\section{AUTHOR BIOGRAPHIES}

Natasha Robbetze is currently a lecturer in the School of Accounting Sciences at the North West University, Vanderbijlpark Campus, South Africa, where she teaches Financial Accounting modules to undergraduate students. She holds a Masters in Commerce degree (Accountancy) (cum laude) from the North West University.

Rikus de Villiers is currently a senior lecturer in the School of Accounting Sciences at the North West University's Potchefstroom Campus. He holds a PhD in Accountancy. He is a member of the South African Institute of Chartered Accountants. Research interests include Accounting, Accounting Education and Finance.

Lana Harmse is currently a senior lecturer in the School of Accounting Sciences at the North West University's Vaal Triangle Campus. She holds two Master's degrees: one in SA \& International Tax and one in Forensic Accounting. She is a member of the South African Institute of Professional Accountants and worked in the Transfer Pricing department at $\mathrm{PwC}$ after completion of her articles.

\section{REFERENCES}

Adams, K \& Media, D. (2014). Objectives of financial statements. Retrieved from http://www.smallbusiness.chron.com/ objecives-financial-reporting-25342.html

Almumani, M.A. (2014). Determinants of equity share prices of the listed banks in Amman Stock Exchange: quantitative approach. International Journal of Business and Social Science, 5(1), 91-104.

Auret, C.J. \& De Villiers, J.U. (2000). A comparison of earnings per share and dividends per share as explanatory variables for share prices. Journal for Studies in Economics and Econometrics, 24(1), 39-53.

Baker, H.K. \& Haslam, J.A. (1973). Information needs of individual investors. Journal of Accountancy, 4(4), 64-69.

Balsam, S. \& Lipka, R. (1998). Share prices and alternative measures of earnings per share. Accounting Horizons, 12(3), 234249.

BDO. (2014). IFRS at a glance: IAS33 - earnings per share. Retrieved from http://bdointernational.com/services/Audit/ IFRS/IFRS\%20at\%20a\%20Glance/Documents/IAS\%2033.pdf

Blume, M.E. \& Friend, I. (1978). The changing role of the individual investor: a twentieth century fund report. New York, NY: Wiley.

Bragg, S. (2013). What are headline earnings. Retrieved from http://www.accountingtools.com/what-are-headlineearnings.html

Brigham, E.F. \& Ehrhardt, M.C. (2007). Financial Management: Revised Custom Edition. Belmont, CA: Cengage Learning.

Chang, H., Su, C., Chen, Y. \& Chang, Y. (2008). The relationship between stock price and EPS: evidence based on Taiwan Panel Data. Economics Bulletin, 3(30), 1-12.

De Villiers, J.U., Hamman, W.D., Joubert, C. \& Le Roux, N.J. (2003). Earnings per share and cash flow per share as determinants of share value: tests of significance using the bootstrap with Demsetz's method. Journal of Studies in Economics and Econometrics, 27(1), 95-125.

De Wet, J.H.V.H. \& Du Toit, E. (2007). Return on equity: a popular, but flawed measure of corporate financial performance. South African Journal of Business Management, 38(1), 59-69.

Demsetz, H. (1995). The use and abuse of accounting profit data. In H. Demsetz (Eds.), The economics of the business firm: seven critical commentaries. Cambridge, MA: Cambridge University Press.

Dunn, J. (2010). Financial reporting and analysis. West Sussex, England: Wiley.

Erasmus, P.D. (2010). Earnings, dividends and cash flow volatility: a South African perspective. Corporate Ownership \& Control, 8(1), 508-514.

Field, A. (2009). Discovering statistics using SPSS. (3rd ed.). Oaks, CA: Sage.

Haque, S. \& Faruquee, M. (2013). Impact of fundamental factors on stock prices: a case based approach on pharmaceutical companies listed with Dhaka Stock Exchange. International Journal of Business and Management Invention, 2(9), $34-$ 41.

Hinman, D.L. (2014). Reality driven investing: statistics that make a difference. Bloomington, IN: Xlibris Publishing.

Huizingh, E. (2007). Applied statistics with SPSS. Oaks, CA: Sage.

IFRS. (2014). A guide through IFRS: Part A2. United Kingdom: IFRS Foundation Publications.

Iqbal, A., Ahmed, F., Zaidi, S.S.Z. \& Raza, H. (2015). Determinants of share prices, evidence from Oil and Gas and Cement sector of Karachi Stock Exchange (A Panel Data Approach). Journal of Poverty, Investment and Development, 8(1), 14-19.

Jagongo, A. \& Mutswenje, V.S. (2014). A survey of the factors influencing investment decisions: the case of individual investors at the NSE. International Journal of Humanities and Social Science, 4(4), 92-101.

Kennon, J. (2014). Basic vs diluted earnings per share: analysing an income statement. Retrieved from 
http://www.beginnersinvest.about.com/od/incomestatementanalysis/a/basic-eps-diluted-eps.htm

Koppeschaar, Z.R., Sturdy, J., Du Toit, E., Deysel, D.J., Rossouw, J., Van Wyk, H.A., Gaie-Booysen, F.F., Papageorgiou, K., Smith, C. \& Van der Merwe, C.M. (2013). Descriptive accounting: IFRS focus. (18 ${ }^{\text {th }}$ ed.). Pretoria: Van Schaik.

Leedy, P.D. \& Ormrod, J.E. (2001). Practical research: planning and design. (11th ed.). Englewood Cliffs, NJ: Prentice Hall.

Lev, B. (1989). On the usefulness of earnings and earnings research: lessons and directions from two decades of empirical research. Journal of Accounting Research, 27(3), 153-191.

May, M.M. (1968). The earnings per share trap. Financial Analysts Journal, 24(3), 113-117.

Menaje, P.M. (2012). Impact of selected financial variables on share price of publicly listed firms in the Philippines. American International Journal of Contemporary Research, 2(9), 98-104.

Menike, M.G.P.D. \& Prabath, U.S. (2014). The impact of accounting variables on stock price: evidence from the Colombo Stock Exchange, Sri Lanka. International Journal of Business and Management, 9(5), 125-137.

Minton, B.A., Schrand, C.M. \& Walther, B.R. (2002). The role of volatility in forecasting. Retrieved from http://fisher.osu.edu/supplements/10/10953/minton-schrand-walther-RAS-2002.pdf

Mkhonza, R.V. (2007). The influences of share buyback schemes on earnings per share and profitability of listed companies in South Africa (Masters dissertation). University of Johannesburg, Johannesburg, South Africa.

Mlonzi, V.F., Kruger, J. \& Ntoesane, M.G. (2011). Share price reaction to earnings announcement on the JSE-AltX: A test for mark efficiency. Southern African Business review, 15(3), 142-166.

Moles, P., Parrino, R. \& Kidwell, D. (2011). Corporate finance. West Sussex, England: Wiley.

Nichols, D.C. \& Wahlen, J.M. (2004). How do earnings numbers relate to stock returns? A review of classic accounting research with updated evidence. Accounting Horizons, 18(4), 263-286.

Oberholster, J.G.I., Koppeschaar, Z.R., Janse van Rensburg, C., Binnekade, C.S., Hattingh, M., De Klerk, M., Rossouw, J. \& Du Toit, E. (2011). Introduction to IFRS. (4th ed.). Johannesburg: LexisNexis.

Pallant, J. (2013). SPSS survival manual. (5th ed.). New York, NY: McGraw-Hill.

Reynders, H.J.J., Lambrechts, I.J. \& Scheurkogel, A.E. (1984). Financial Management. Pretoria: Van Schaik.

SAICA. (2013). Headline earnings: Circular 2/2013. Retrieved from http://www.jse.co.za/content/JSECircularItems/ Circular_2_2013_Headline_Earnings.pdf

Sharma, S. (2011). Determinants of equity share prices in India. Journal of Arts, Science \& Commerce, 2(4), 51-60.

Smart, S.B. \& Graham, J.R. (2012). Introduction to financial management. (3rd ed.). Belmont, CA: Cengage Learning.

Steenkamp, M. (2013). Headline earnings per share (HEPS) - Part 2 How calculate HEPS. Retrieved from http://www.rsmbettyanddickson.co.za/Articles/Article-Heps-How-to-calculate-Part2.aspx

Vaidya, D. (2014). Dummies guide to earnings per share. Retrieved from http://www.wallstreetmojo.com/earnings-per-sharebasic-eps-diluted-eps.html 


\section{NOTES}

